\title{
SEISMIC PERFORMANCE STUDY ON RC WALL BUILDINGS FROM PUSHOVER ANALYSIS
}

\author{
Rajesh M N ${ }^{1}$, S K Prasad ${ }^{2}$ \\ ${ }^{1}$ PG Student, Department of Civil Engineering, Sri Jayachamarajendra College of Engineering, Karnataka, India \\ ${ }^{2}$ Professor, Department of Civil Engineering, Sri Jayachamarajendra College of Engineering, Karnataka, India
}

\begin{abstract}
Buildings built completely with RC walls without frame elements are fast gaining popularity especially in urban areas. Advance in formwork technologies have made RC wall buildings an obvious choice for mass constructions because of their economy and speed of construction. Seismic performance of RC walled buildings is of primary concern in the analysis and design of such structures. Modeling of RC walls using layered shell elements has made it possible to accurately model the reinforcement configurations in $R C$ walls and to capture the nonlinear behavior of walls efficiently. With the help of suitable nonlinear material models for concrete and reinforcing steel, pushover analysis can be conveniently adopted to assess the seismic performance RC walled buildings. In the present study, RC walls are modeled and analyzed using SAP 2000's pushover analysis capability on layered shell elements. Various parameters such as aspect ratio of walls, reinforcement detailing aspects and presence of openings are chosen to study the seismic performance of $R C$ walled buildings. Results of analysis have revealed that incorporation of ductile detailing in the form of boundary element significantly improves the seismic performance of $R C$ walls specially the displacement ductility of the wall and the effects are more pronounced when the bottom storeys are strengthened with boundary elements. Presence of openings in RC walls significantly reduces base shear carrying capacity in the presence of boundary elements while it reduces both base shear capacity and ductility in the absence of boundary elements. Decrease in the aspect ratio of the wall reduces the base shear capacity of the wall while deformation capacities remain unaffected.
\end{abstract}

Keywords: RC Wall, Pushover Analysis, Layered Shell, Boundary Elements, Confined Concrete $* * *$

\section{INTRODUCTION}

The disastrous effects of past earthquakes on life and properties have increased the need for a close review of the conventional lateral load resisting systems and to adopt innovative and modified lateral load resisting systems for effective and efficient mitigation of earthquake forces. Dual systems with moment resting frames and shear wall elements have gained significant popularity in the recent years as effective construction methods in high seismicity areas. The significant improvement in the seismic capacity achieved by buildings by the introduction of shear walls have led to the concept of buildings built entirely of reinforced concrete walls popularly called as RC walled buildings.

A RC walled building essentially consists of a load carrying mechanism composed of reinforced concrete (RC) shear walls and slabs only and is being increasingly utilized in the construction of multistory residential units. Monolithic RC walled building constructions are also referred to as 'Box Construction' and 'Tunnel Form Construction'. Tunnel form buildings provide superior seismic performance compared to conventional RC frame and dual systems, which suffered significant damage and total collapse in many regions during recent devastating earthquakes [1]. Apart from its enhanced seismic performance, RC walled buildings also offer the advantage of increased floor area owing to the presence of thin wall elements (as low as $100 \mathrm{~mm}$ ) as opposed to heavy columns and masonry walls.
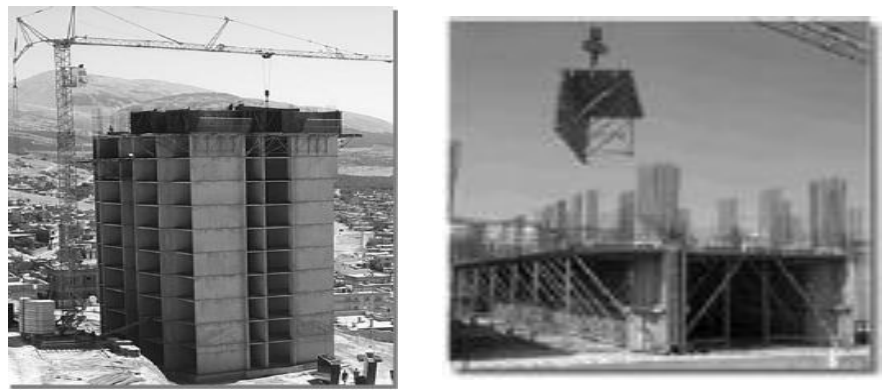

Fig-1: RC Wall (Tunnel Form) Construction

Recent advances in formwork technology have made RC wall buildings an attractive and affordable choice of construction especially for mass housing applications. Advent of 'Mivan' formwork systems has significantly increased the speed of constructions of RC wall buildings. This technology involves pre-fabricated formwork units and facilitates casting of an entire floor (including wall and slab arrangement) monolithically. Speed of construction as high as 4 to 5 days per floors can be easily achieved. This monolithic action of 
slabs and walls is one of the main attributes enhancing the seismic performance of these structures. Apart from mass house application, RC walls are the obvious choice for lift core walls, chemical and nuclear containers and other special applications.

Though RC walled buildings are supposed to perform well in the event of an earthquake, their seismic performance is always of interest. Presence of openings, irregularities, unusual slenderness and lack of proper ductile reinforcement are likely to cause failures in RC walls. Many such instances of RC wall failures (Fig-2) can be found during past earthquakes [2]. Also, there is acute shortage of codal provisions and specifications for the seismic resistant design of RC wall buildings. Hence, it is intended to study the seismic performance of RC wall buildings in the present work.

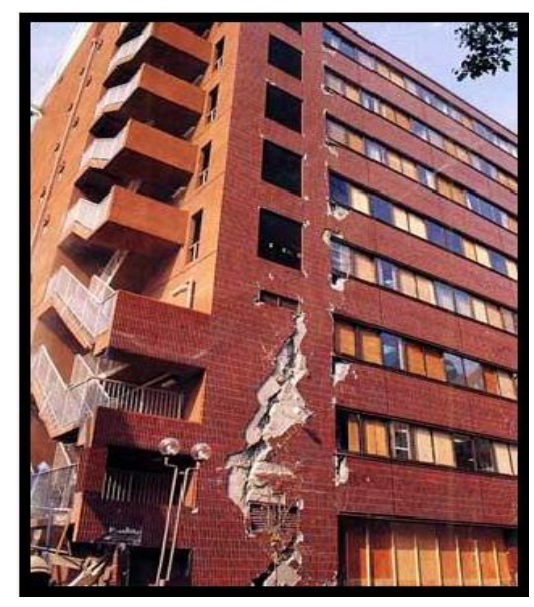

Fig-2: Concrete Wall Failing in 1995 Kobe Earthquake

\section{PUSHOVER ANALYSIS ON RC WALL BUILDING}

Non-linear static (Pushover) analysis is considered as a powerful tool to assess the capacity of structure and hence is able to predict the actual behavior of the structure during earthquake. Pushover analysis essentially consists of subjecting the structure to a monotonically increasing load in a direction and plotting the base shear versus monitored displacement at the roof top which forms the capacity curve. The curve in then superimposed on the demand imposed by the earthquake forces to assess the level of performance of the structure.

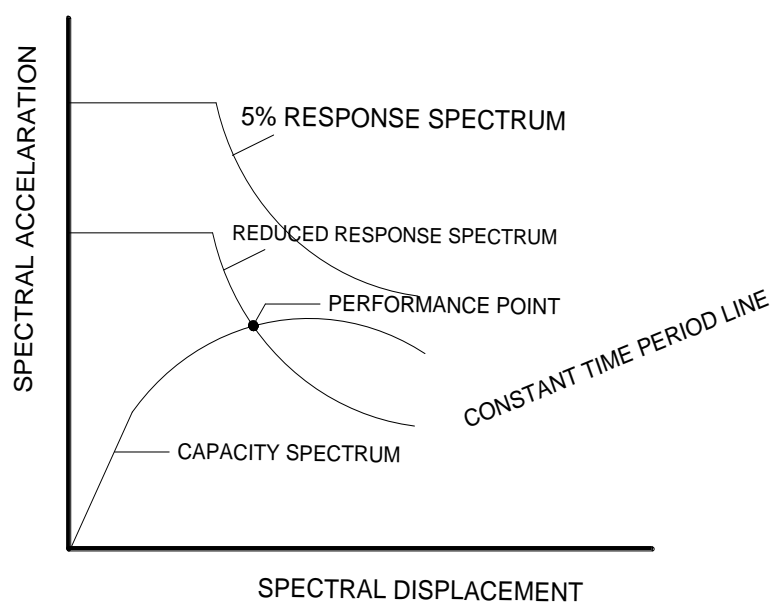

Fig-3: Pushover Analysis

Traditional method of analysis for RC walls involves modeling of $\mathrm{RC}$ walls using equivalent frame elements and hinge properties based on ATC-40 [3] hinge definition for walls and coupling beams (spandrels). But, it is not always convenient to model all $\mathrm{RC}$ walls using equivalent frame elements. This methodology of modeling poses serious limitations when a three dimensional model of RC wall building is to be prepared. These models also possess the limitation of inaccurate modeling of reinforcement patterns and inability to accurately capture the material non-linear behavior using suitable non-linear models.

\subsection{Modeling of RC Walls Using Layered Shell}

\section{Elements}

One of the important pre-requisites for layered shell model is adopting a suitable non-linear material model for concrete and steel. Here, RC wall is modeled using a fine mesh of smeared multi-layer shell elements. The multi-layer shell element is based on the principles of composite material mechanics. The shell element is made up of many layers with different thickness and different material properties (Fig-4). This means that the reinforcement rebars are modeled as various layers within the concrete element. During the finite element calculation, the axial strain and curvature of the middle layer can be obtained in one element. Then according to the assumption that plane remains plane, the strains and the curvatures of the other layers can be calculated and then the corresponding stress will be calculated through the constitutive relations of the material assigned to the layer. From the above principles, it is seen that the structural performance of the RC wall can be directly connected with the material constitutive law. 


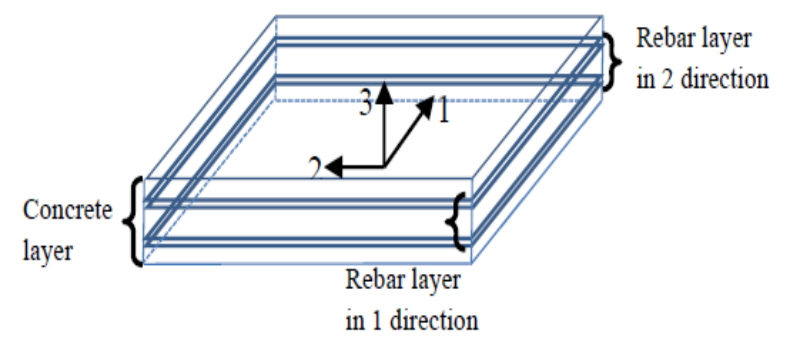

Fig-4. Layered Shell Element

\section{SEISMIC BEHAVIOR OF RC WALL BUILDINGS}

Owing to their monolithic nature and presence of reinforcement distributed throughout the members in the form of a mesh, RC walls perform much better in the event of an earthquake compared RC framed structures. RC wall structures are generally associated with high strength, high stiffness and high ductility characteristics (Fig-5). Walls act as vertically oriented wide beams causing smooth transfer of seismic forces. However, behavior of RC walls critically depends on many factors such as reinforcement pattern, aspect ratio of the walls, material properties, presence of openings and so on. The effect of these parameters on the seismic behavior of RC walls should be established carefully. Any abrupt changes in these parameters can lead to poor performance of RC walls. General modes of failure of a shear wall include overturning failure, shear failure and sliding failure.

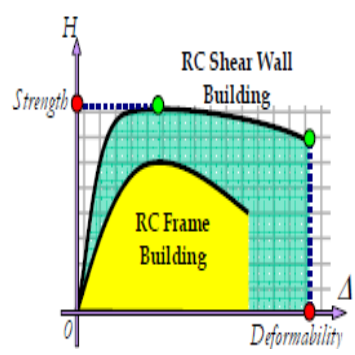

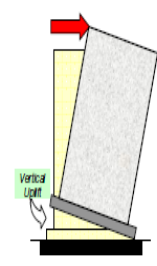

overturnin $\mathrm{g}$

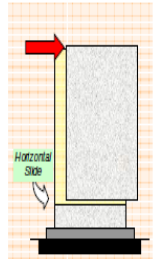

sliding

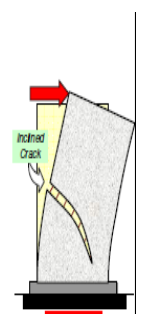

Shearin $\mathrm{g}$
Fig-5: Seismic Behavior of RC Wall Buildings [7]

One of the most important factors controlling the behavior of $\mathrm{RC}$ wall buildings is the pattern or detailing of reinforcement. Reinforcement controls both strength and deformation characteristics of the walls. For a good seismic performance of walls, continuous reinforcement in the form of a close mesh with proper splices should be provided. In case of highly stressed RC walls, the wall sections should be strengthened with boundary elements with special confining reinforcement. Indian Standard code on ductile detailing [6] requires regions of wall where the extreme concrete stress due to dead and factored earthquake load exceeds $0.2 . f_{\text {ck }}$ to be strengthened with boundary elements. The boundary elements may be discontinued where the calculated compressive stress becomes less than $0.15 f \mathrm{ck}$. Presence of boundary elements in the critical regions enhances both strength and ductility of walls [7].
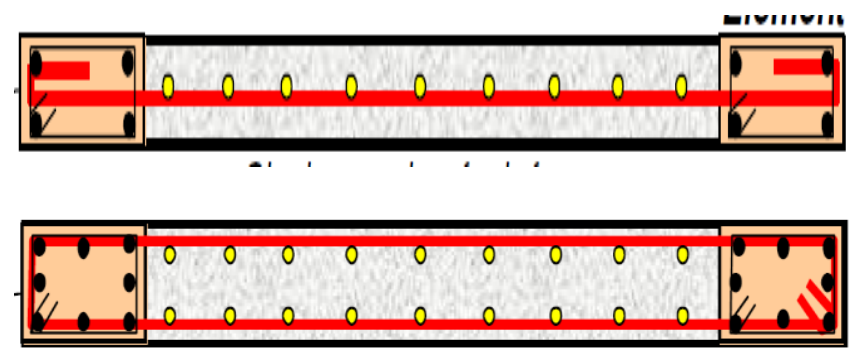

Fig-6: Walls Strengthened with Boundary Elements

Presence of openings cannot be avoided in RC wall buildings from the functional requirements point of view. However, openings pose serious problems of stiffness irregularities in walls. Both stiffness and deformation characteristics of wall are significantly degraded due to the presence of openings. Presence of large openings makes the portions of the wall above the openings to act as coupling beams or spandrels which significantly increase the ductility demand of the walls [7]. Large and unsymmetrically placed openings should be avoided in the walls. Openings should be kept as small as possible and its uniform distribution should be maintained.
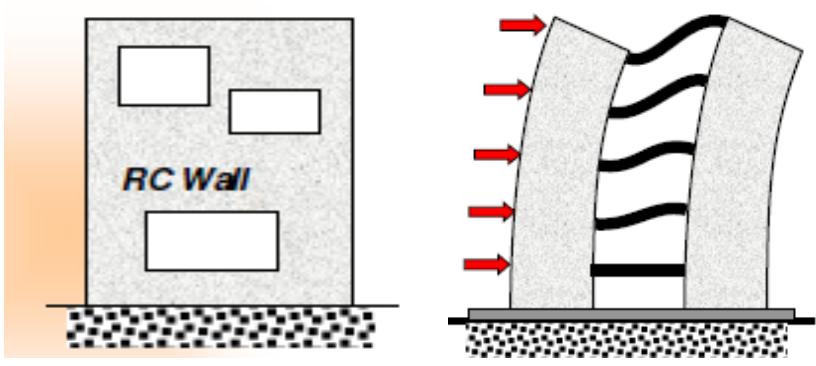

Fig-7: Presence of Openings in RC Walls [7]

Aspect ratio of the $\mathrm{RC}$ walls is another important factor affecting the seismic performance of walls. If the wall is too stocky, it tends to develop shear cracks during an earthquake which is undesirable. At the same time, care should be taken to see that wall is not made very narrow. Walls that are too narrow are more vulnerable to seismic failure than stocky walls. Narrow wall tends to overturn under earthquake loads and causes local soil failure due to the development of high bearing pressure. 


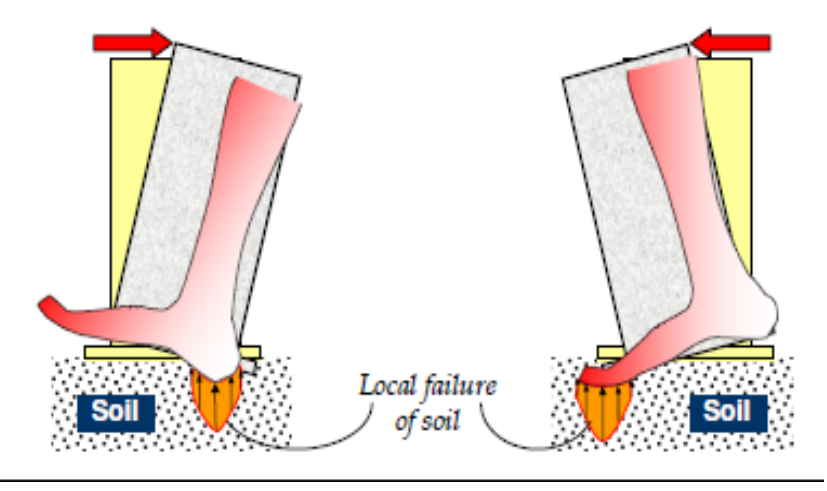

Fig-8: Failure of Narrow Walls [7]

In the present study, an attempt is made to illustrate the effect of all these parameters on the seismic behavior of walls using pushover analysis.

\section{MODELING AND ANALYSIS}

In the present work, a six-storey RC wall building is modeled by using 2D idealization and analyzed using SAP2000's[5] pushover analysis capabilities. Mander model for confined and unconfined concrete and Park model for reinforcing steel which are available in SAP2000 are used as nonlinear material models. Concrete wall is typically of $300 \mathrm{~mm}$ thickness with M25 concrete and Fe 415 steel.
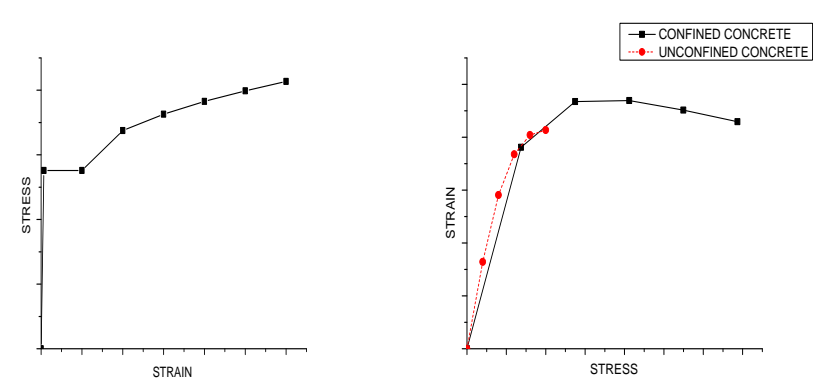

Fig-9 Typical Material Models for Steel and Concrete

The Dead load and live load from the tributary slab areas are applied as distributed loads on the wall. Pushover analysis is typically of displacement control type with loads applied as uniform acceleration in the lateral directions. The resulting base shears and roof top displacements are monitored to plot the pushover curve.

\section{RESULTS AND DISCUSSION}

An attempt is made to study the effect of detailing aspects, presence of openings and aspect ratio of walls on the seismic performance of RC wall structure. The resulting capacity curve from the pushover analysis and the stress conditions at various stages of pushover analysis are used to study the effect of these parameters on the seismic performance of walls.

\subsection{Effect of Reinforcement Configuration}

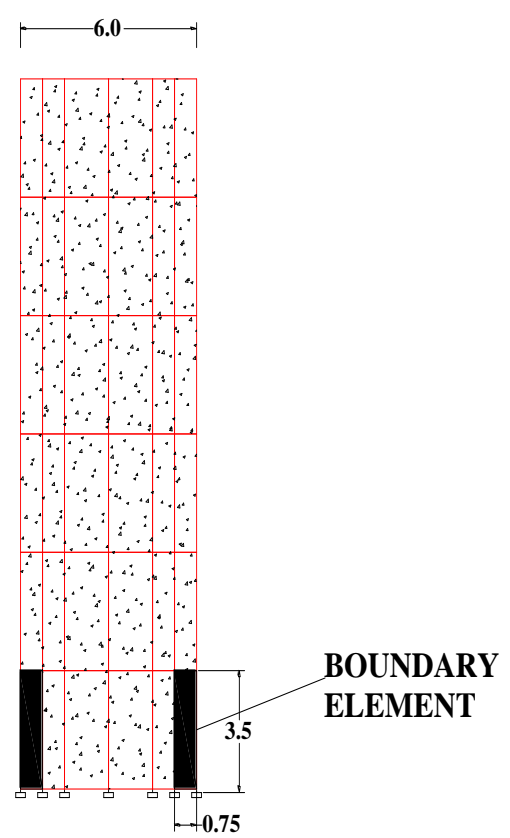

Fig-10: Wall modeled with Boundary Elements at the Bottom Storey

A typical 6-storey RC wall element is modeled as in Fig-10. The wall elements are modeled with unconfined concrete and a reinforcement percentage of $0.5 \%$ while the boundary elements are modeled with confined concrete and a reinforcing ratio of $3 \%$ as per the design requirements.

Four different cases with different arrangements of boundary elements are modeled.

Case 1: No boundary elements

Case 2: Boundary elements in bottom storey only

Case 3: Boundary elements in bottom two storeys

Case 4: Boundary elements in bottom three storeys

The resulting pushover curves are as shown in Fig-11. RC wall with no boundary elements has very low base shear capacity and displacement ductility. Incorporation of boundary elements in the bottom storey significantly improves the base shear capacity and displacement ductility of the structure. Further incorporation of boundary elements in the bottom two storeys does not significantly improve the base shear capacity of the structure but there is considerable improvement in the ductility of the wall. Incorporation of boundary elements in further storeys does not result in any improvement. 


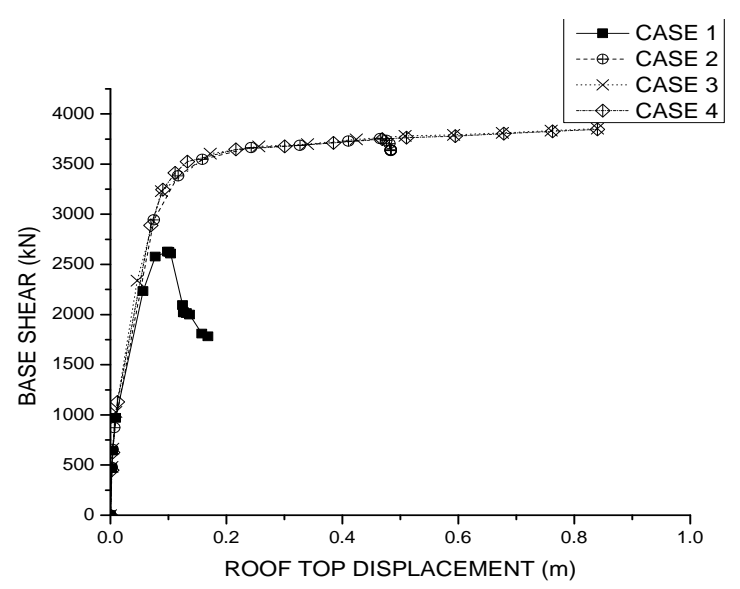

Fig-11: Pushover Curves for Different Configurations of Boundary Elements

The vulnerable locations to be improved with boundary elements for optimum improvement in seismic performance can be located by studying the stresses developed in concrete at the performance point. It is found that the compressive stress value of $0.25 \mathrm{f}_{\mathrm{ck}}$ is exceeded in the bottom two storeys of the wall (Fig-12). Hence boundary elements in the bottom two storeys are effective in improving the seismic capacity of the structure.
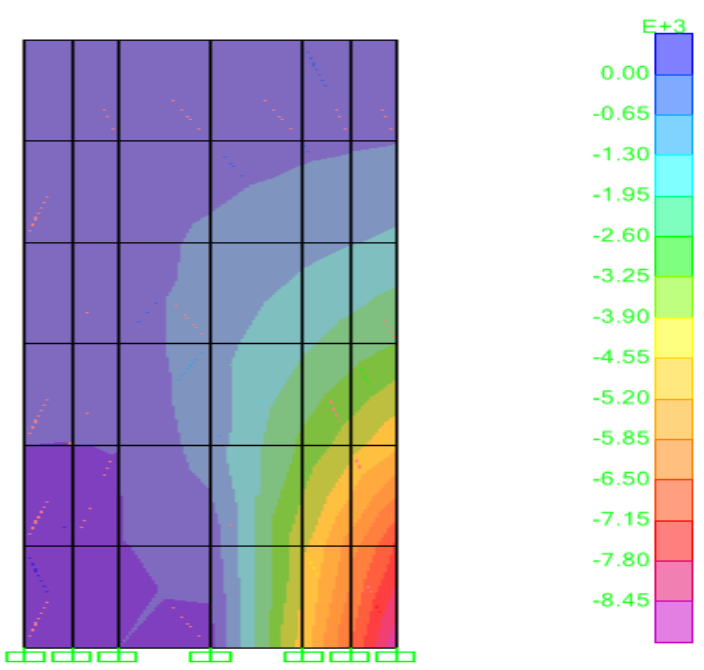

Fig-12: Stresses in Concrete During Pushover Analysis at the Performance Point

\subsection{Effect of Openings in RC Walls}

In order to study the effect of openings on the seismic behavior of RC walls on the same model, four different models with different percentages of openings are considered as shown in the Fig-13. Further, two different cases of walls one without the presence of boundary elements and the other strengthened with boundary elements are considered to study the effect of boundary elements on the wall.

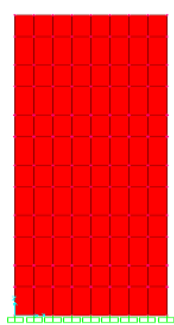

$0 \%$ opening

Type 1

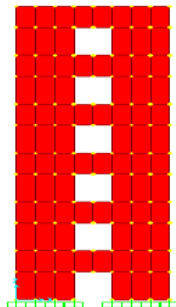

$20 \%$ Type 2 opening

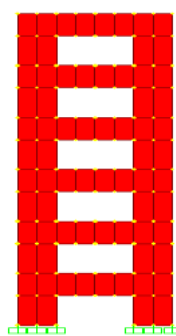

$40 \%$ opening Type 3

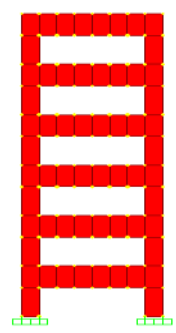

$60 \%$ opening

Type 4
Fig-13: RC Walls with Different Percentage of Openings

Results of the analysis are in Fig-14 and Fig-15. It can be seen that the presence of openings reduces the base shear capacity of the wall significantly in walls strengthened with boundary elements. While in the walls without boundary elements presence of opening not only reduces the base shear capacity of the wall but also degrades the post yield stiffness of the wall and affects its ductility.

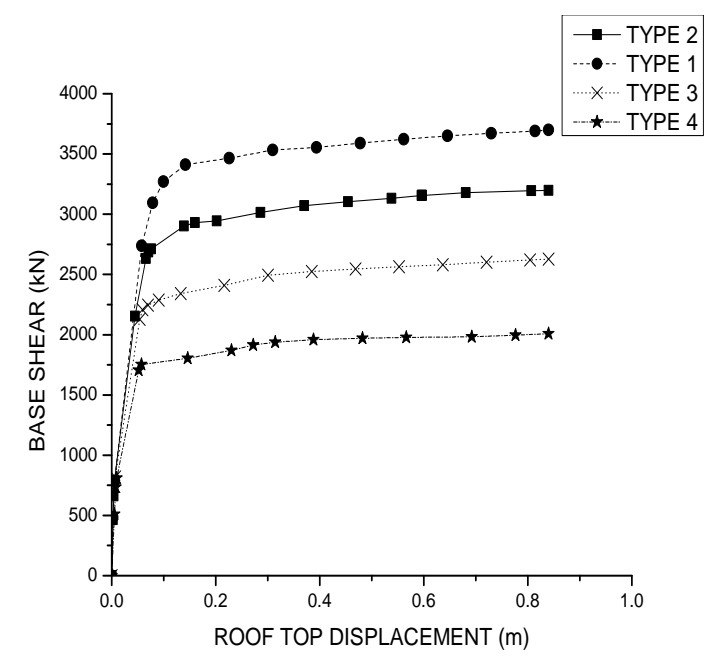

Fig-12: Pushover Curves for Different Percentage of Openings for Wall Strengthened with Boundary Elements 


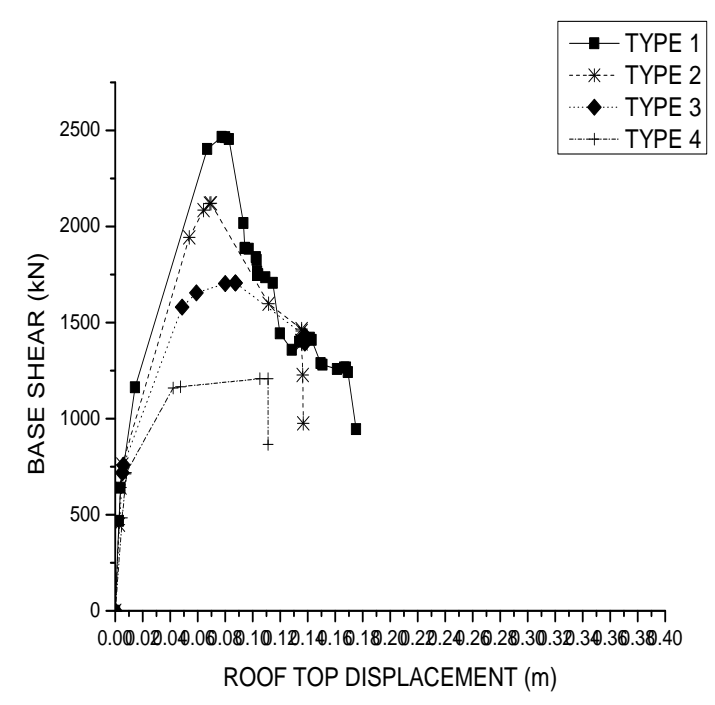

Fig-13: Pushover Curves for Different Percentage of Openings for Wall without Boundary Elements

A review of stresses at the performance point in the pushover analysis clearly illustrates the stress concentration at the corners of the opening and the severity of stress concentration is more at the bottom storeys (Fig-14).
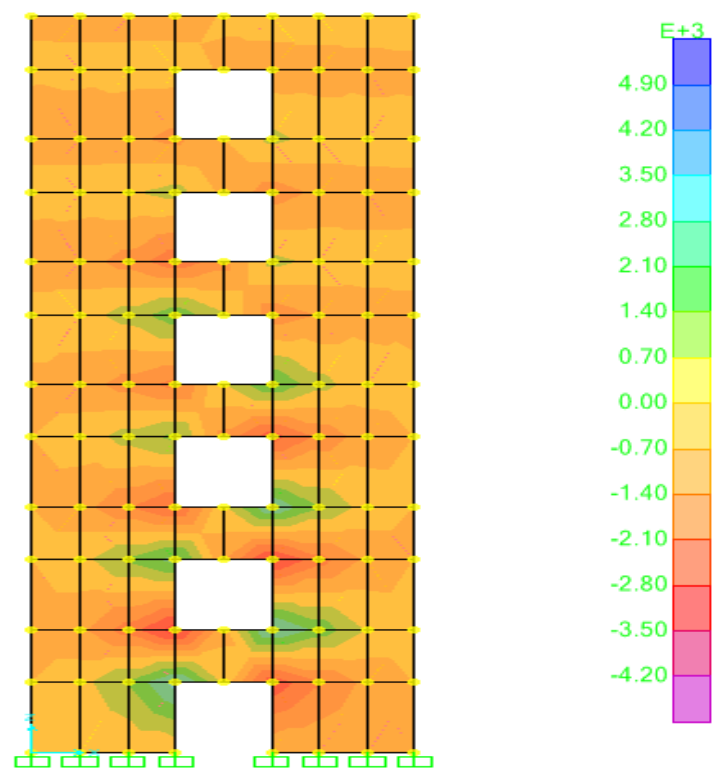

Fig-14: Stresses Developed in Concrete at the Performance Point of Pushover Analysis

\subsection{Effect of Aspect Ratio of Walls}

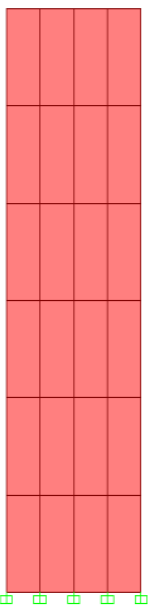

Aspect Ratio

$$
=2
$$

Type A

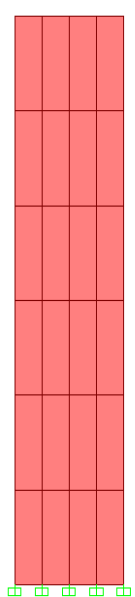

Aspect Ratio

$=1.5$

Type B

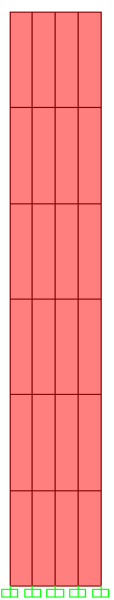

Aspect Ratio

$=1$

Type C

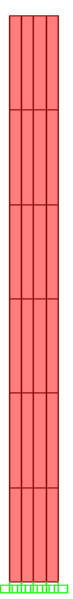

Aspect

Ratio $=0.5$

Type D
Fig-15: Walls with Different Aspect Ratios Considered

Aspect ratio is defined as the ratio of width of the wall to the height of one floor of wall for the purpose of present study. In order to evaluate the effect of aspect ratio of walls, four different models with aspect ratios varying from 2 to 0.5 as shown in Fig-15 are considered. The results of analysis are as shown in Fig-16. From pushover analysis, it is clear that the effect of decrease in aspect ratio (or increase in slenderness ratio) is to decrease the base shear capacity of the wall while the displacement ductility of the structures remains unaffected.

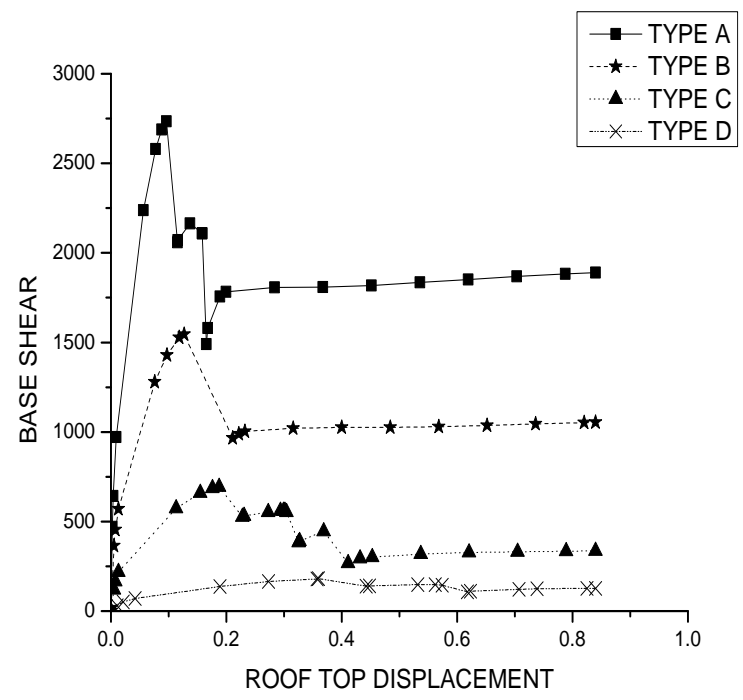

Fig-16: Pushover Curves for Different Aspect Ratios of RC Walls 


\section{CONCLUSIONS}

In the present study an attempt is made to study the effects of various parameters that influence the seismic behavior of $\mathrm{RC}$ walls. A typical 6-storey $\mathrm{RC}$ wall element is modeled and analyzed using SAP 2000's pushover analysis capabilities. Following are the conclusions drawn from the present study.

- Modeling of RC wall elements using layered shell elements is a convenient and accurate method in pushover analysis.

- Incorporation of ductile detailing in the form of boundary elements improves the base shear capacity and displacement ductility of the structures

- Regions of the wall which are likely to be overstressed due to earthquake loads can be strengthened with boundary elements to improve the ductility of the wall. Hence, effect of ductile reinforcement is more pronounced in lower two storeys.

- Presence of openings in a RC wall decreases the base shear carrying capacity of the wall in those strengthened with boundary elements. In the absence of boundary elements, presence of openings not only reduces base shear carrying capacity, but also results in degradation of post yield stiffness and deformation capacity of the wall.

- Decrease in the aspect ratio of the wall decreases the base shear capacity of the structure while the deformation capacities of the walls remain unaffected.

\section{REFERENCES}

[1]. Erol Kalkanand and Bahadir Yüksel.S (2007), "Pros and Cons of Multistory RC Tunnel-Form (Box-Type) Buildings", The Structural Design of Tall and Special Buildings, Published online in Wiley Inter science (www.interscience.wiley.com).

[2]. Garrett Richard Hagen (2012), "Performance-Based Analysis of a Reinforced Concrete Shear Wall Building", Thesis presented to the Faculty of California Polytechnic State University, San Luis Obispo.

[3]. Applied Technology Council (ATC 40) document, (1996)

"Seismic Evaluation and Retrofit of Concrete Buildings", Vol. 1, Report no. SSC 96-01, California.

[4]. Fahjan.Y, Doran.B, Akbas.B and Kubin.J (2012), "Pushover Analysis for Performance Based-Seismic Design of RC Frames with Shear Walls", 15 WCEE, Lisboa,

[5]. CSI (2009), SAP2000: Static and Dynamic Finite Element Analysis of Structures 14.0, Computers and Structures, Inc., Berkeley, California.

[6]. IS 13920:1993, "Indian Standard Code of Practice for Ductile Detailing of Reinforced Concrete Structures Subjected to Seismic Forces", Bureau of Indian Standards, New Delhi.
[7] Durgesh C Rai (2012), "Short Course on Seismic Design of RC Structures", Department of Civil Engineering, IIT Kanpur.

\section{BIOGRAPHIES}

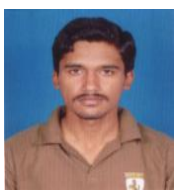

Rajesh M N has graduated from PES College of Engineering Mandya, securing 4th rank for Visvesvaraya Technological University. After a year of experience in the construction industry, he is presently perusing M.Tech degree in Industrial Structures at Sri Jayachamarajendra College of Engineering, Mysore.

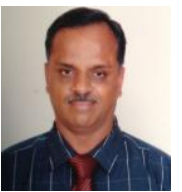

Dr $\mathrm{S} K$ Prasad is a graduate from civil engineering securing first rank to Mysore university. He has his master's degree from IIT Kanpur and Ph.D. from University of Tokyo, Japan. He has more than 85 technical papers to his credit and he is a distinguished member of various scientific and professional societies. With over 25 years of teaching experience, he is currently serving as professor in civil engineering at Sri Jayachamarajendra College of Engineering, Mysore. 